0016-7037(94)00360-2

\title{
Miocene basalts in northwestern Taiwan: Evidence for EM-type mantle sources in the continental lithosphere
}

\author{
Sun-Lin Chung, ${ }^{1,2, *}$ Bor-Ming JAHn, ${ }^{2}$ Shu-Jen Chen, ${ }^{1}$ Typhoon Lee, ${ }^{1,3,4}$ and Cheng-Hong Chen ${ }^{1}$ \\ 'Department of Geology, National Taiwan University, 245 Choushan Road, Taipei, Taiwan, Republic of China \\ ${ }^{2}$ Géosciences Rennes, Université de Rennes 1, F-35042 Rennes Cedex, France \\ ${ }^{3}$ Institute of Earth Sciences, Academia Sinica, Nankang P.O. Box 1-55, Taipei, Taiwan, Republic of China \\ ${ }^{4}$ Department of Physics, National Taiwan University, Taipei, Taiwan, Republic of China
}

(Received February 21, 1994; accepted in revised form October 10, 1994)

\begin{abstract}
Cenozoic extension around the Taiwan Strait resulted in intraplate basalt volcanism in the Fujian-Taiwan region of the southeastern China continental margin. In northwestern Taiwan, the basalt volcanism took place in two distinct periods: the early Miocene (23-20 Ma), with the eruption of alkali basalt only, and the late Miocene (13-9 Ma), marked by the emplacement of various basalt types. The early Miocene basalts have uniform $\mathrm{Sr}-\mathrm{Nd}-\mathrm{Pb}$ isotope compositions comparable with those of the other Fujian-Taiwan basalts, which are believed to have originated from a "plum-pudding" type convecting mantle. These basalts display EM2-type lead isotope signature like that observed in seamount basalts from the South China Sea. By contrast, the late Miocene basalts show distinctive isotope characteristics indicating additional involvement of an EM1-type mantle source that has never been identified before for any volcanics in southern China. We propose that the "enriched mantle" components (EM1 and EM2) reside in different levels of the continental lithospheric mantle. Reactivation of the unique EM1 source may be ascribed to the arc-continent collision in Taiwan during the last 12 million years which terminated the intraplate volcanism around this region.
\end{abstract}

\section{INTRODUCTION}

Two main tectonic processes are generally considered to account for Cenozoic continental extension and generation of intraplate basalts in eastern China. The first is the collision between the India and the Eurasia that reactivated many old trans-lithospheric faults and initiated a tensile setting in eastern Asia (Tapponnier et al., 1986). The second is the subduction of the Pacific plate underneath Eurasia, which may be particularly important to the "back-arc" region surrounding the Sea of Japan and northeastern China (Tatsumi et al., 1989). In general, Cenozoic basalts in eastern China show chemical and isotopic systematics similar to those of oceanic island basalts (Zindler and Hart, 1986; Sun and McDonough, 1989). They furthermore have higher ${ }^{208} \mathrm{~Pb} /{ }^{204} \mathrm{~Pb}$ and ${ }^{207} \mathrm{~Pb} /$ ${ }^{204} \mathrm{~Pb}$ ratios than the Northern Hemisphere Reference Line, characteristic of the Dupal isotope anomaly commonly observed in oceanic basalts of the southern hemisphere (Hart, 1984). Consequently, the continental lithospheric mantle has been widely suggested as an additional source to the asthenosphere that may be involved in basalt genesis (Song et al., 1990; Basu et al., 1991; Zartman et al., 1991; Tu et al., 1992; Chung et al., 1994).

Tapponnier et al. (1986) proposed that the India-Eurasia collision has played a key role in opening of the South China Sea (32-15 Ma). A northeastward propagation of this dilational stress created a rifting tectonic regime around the Taiwan Strait and resulted in the emplacement of intraplate basalts in the Fujian-Taiwan region (Fig. 1). These basalts display a spatial chemical and isotopic variation reflecting interaction between the upwelling asthenosphere and the basal

\footnotetext{
* Author to whom correspondence should be addressed.
}

continental lithosphere (Chung et al., 1994). However, this rifting ceased with the collision of the Luzon arc and the Asian continent in Taiwan which began at ca. 12 Ma (Teng, 1990). Therefore, Miocene basalts in northwestern Taiwan are particularly important in understanding mantle processes during a change of tectonic environment from continental rifting to arc-continent collision.

In this paper, we report chemical and $\mathrm{Sr}-\mathrm{Nd}-\mathrm{Pb}$ isotopic data of Miocene basalts in northwestern Taiwan with the following purposes: (1) to document the temporal and spatial variation in chemical and isotopic compositions of these basalts; (2) to characterize the EM-type continental lithospheric mantle sources involved in intraplate volcanism; and (3) to discuss possible processes for the generation of different lithospheric mantle reservoirs and their roles in magma genesis.

\section{SAMPLES AND ANALYTICAL METHODS}

The active mountain belts in Taiwan are created by the collision of the Luzon arc and the Asian continent (Ho, 1986; Teng, 1990). In northwestern Taiwan, basaltic rocks occur as lenticular bodies in the Neogene continental shelf sedimentary sequences which, due to the arc-continent collision, have been transported ca. $200 \mathrm{~km}$ from the southeast (Suppe, 1981) and emplaced in a fold-and-thrust belt (Fig. 1). Two main stages of basalt volcanism are recognized in the early Miocene (Kungkuan Stage) and the late Miocene (Chiaopanshan Stage) (Yen, 1958). In general, they are represented by basalt eruptions in the Kungkuan (23-20 Ma) and Kuanhsi-Chutung (13-9 Ma) areas, respectively. The Kungkuan volcanics consist predominantly of alkali basalts, whereas rocks in the Kuanhsi-Chutung area comprise variable types including basanite, alkali basalt, transition basalt, tholeiitic basalt, and highly potassic basalt (Chen Cheng-Hong, 1990).

Basalt samples collected from the two areas were first crushed into gravel-size chips. Clean chips were then pulverized in a corundum mill for elemental and strontium and neodymium isotopic determinations. All major and some trace element $(\mathrm{Rb}, \mathrm{Ba}, \mathrm{Nb}, \mathrm{Sr}, \mathrm{Zr}, \mathrm{Y}, \mathrm{V}$, 


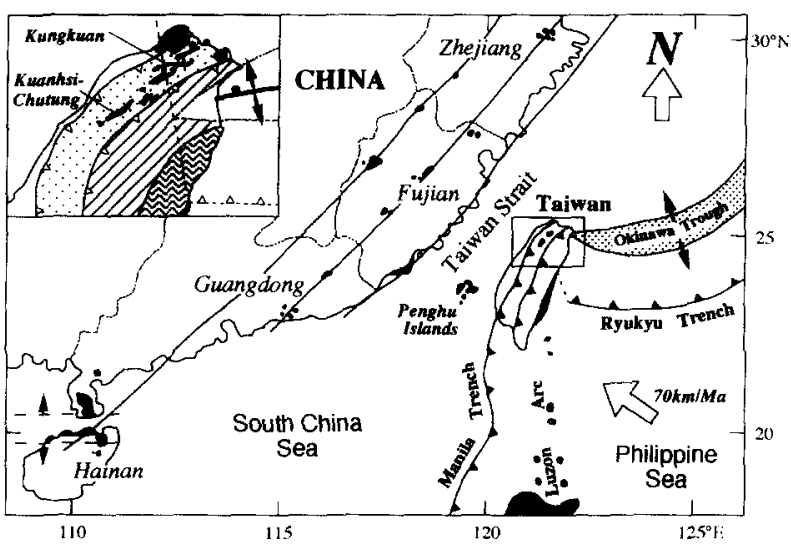

Fig. 1. A map showing the tectonomagmatic framework of South China and the adjacent region. Black areas mark outcrops of late Cenozoic intraplate basalts. The inset outlines two major locations of Miocene basalts in the fold-and-thrust belt of northwestern Taiwan.

$\mathrm{Ga}, \mathrm{Cu}, \mathrm{Zn}, \mathrm{Ni}$, and $\mathrm{Cr}$ ) compositions were determined at the Université de Rennes by X-ray fluorescence (XRF) method using a Philips PW1404 spectrometer. The other trace element abundances were determined by instrumental neutron activation analyses (INAA) at the National Taiwan University. Analytical uncertainties are generally better than $5 \%$ for the XRF and 5-15\% for the INAA methods. To evaluate the effects of subaerial alteration that may be significant in some Fujian-Taiwan basalts (Chung et al., 1994), four Kuanhsi-Chutung samples were analyzed before and after acid leaching $\left(100^{\circ} \mathrm{C}, 2\right.$ $\mathrm{N} \mathrm{HCl}$, overnight) for strontium isotopes. All acid-leached samples have lower ${ }^{87} \mathrm{Sr} /{ }^{86} \mathrm{Sr}$ ratios and only sample $\mathrm{S}-14$ shows a decrease in ${ }^{87} \mathrm{Sr} /{ }^{86} \mathrm{Sr}$ ratio from 0.70463 to 0.70424 (Table 1). Small chips were used for lead isotope analyses. They were washed with deionized water several times and then leached with hot $2 \mathrm{~N} \mathrm{HCl}$ for about 30 min before acid dissolution. Most strontium and neodymium isotope ratios were measured by a VG354 mass spectrometer at Academia Sinica, Taipei. Some strontium and neodymium and all lead isotope data were analyzed by a Finnigan MAT262 mass spectrometer at the Université de Rennes. The inter-laboratory reproducibility of isotope data and some details of analytical techniques have been discussed by Chen Chen-Hong et al. (1990).

\section{RESULTS AND DISCUSSIONS}

The analytical results are listed in Table 1 . The primitive mantle normalized diagram (Fig. 2) shows that, despite the difference in age and rock type, the Miocene basalts in northwestern Taiwan are marked by variable degrees of enrichment of the highly incompatible elements without depletions in the high field strength elements (e.g., $\mathrm{Nb}$ and $\mathrm{Ta}$ ). Even for the highly potassic basalt sample (i.e., M-604), no Nb-Ta negative anomaly is observed. In addition, alkali basalts from the Kungkuan and the Kuanhsi-Chutung areas display coherent elemental distribution patterns, resembling those of ocean island basalts (Sun and McDonough, 1989). A comprehensive discussion on the elemental characteristics of late Cenozoic basalts around the Taiwan Strait is to be given in a paper currently in preparation.

\section{EM-Type Isotope Signatures in Northwestern Taiwan Basalts}

The early Miocene Kungkuan basalts have homogeneous $\mathrm{Sr}-\mathrm{Nd}-\mathrm{Pb}$ isotope compositions (Table 1). They are isotopically indistinguishable from Miocene basalts in the Penghu
Islands situated in the Taiwan Strait, falling in the range of the Fujian-Taiwan basalts (Figs. 3 and 4). Their lead isotope ratios display EM2-type character (Fig. 4) and plot above the Northern Hemisphere Reference Line with $\Delta 8 / 4 \mathrm{~Pb}$ and $\Delta 7 /$ $4 \mathrm{~Pb}$ values (defined as the vertical deviations for ${ }^{208} \mathrm{~Pb} /{ }^{204} \mathrm{~Pb}$ and ${ }^{207} \mathrm{~Pb} /{ }^{204} \mathrm{~Pb}$ away from the reference line; Hart, 1984) of 55-60 and 4-6, respectively. On the other hand, isotope compositions of the Kuanhsi-Chutung basalts are distinct from those of the other Fujian-Taiwan basalts (Figs. 3 and 4). Although the ${ }^{87} \mathrm{Sr} /{ }^{86} \mathrm{Sr}$ vs. ${ }^{143} \mathrm{Nd} /{ }^{144} \mathrm{Nd}$ data (Fig. 3) indicate a possible EM2-type source, the lead isotope plots (Fig. 4) clearly demonstrate that additional mixing of an EM1-type component is required in magma generation. These late $\mathrm{Mi}-$ ocene rocks have even higher $\Delta 8 / 4 \mathrm{~Pb}$ and $\Delta 7 / 4 \mathrm{~Pb}$ values of $75-130$ and $9-19$, respectively.

Chung et al. (1994) have noted that the Fujian-Taiwan basalts (excluding those occurring in the Kuanhsi-Chutung area) possess coherent elemental and isotopic characteristics comparable to seamount basalts in the South China Sea (Tu et al., 1992). This can be interpreted to mean that insignificant crustal contamination occurred during magma generation, and, as such, the chemical and isotopic compositions of these intraplate basalts may reflect that of the mantle source regions. Together with the East Taiwan Ophiolite, these rocks define a binary mixing array, best illustrated by the lead isotope compositions (Fig. 4). The East Taiwan Ophiolite is believed to have originated from the spreading center of the South China Sea (Chung and Sun, 1992). If isotopic compositions of the East Taiwan Ophiolite are taken as an endmember representative of the depleted asthenosphere, the isotope systematics of intraplate basalts in the Fujian-Taiwan region, as well as seamount basalts in the South China Sea, can be interpreted by mixing with another endmember of EM2-type character.

Based mainly on strontium and neodymium isotope data, an EM1-type continental mantle source has been suggested to explain certain volcanics in the northern Luzon arc near Taiwan (Chen Chang-Hwa et al., 1990). However, more recently a combined $\mathrm{Pb}-\mathrm{Sr}$-Nd isotope study (McDermott et al., 1993) argues against this suggestion and favors the involvement of three endmembers in the genesis of these arc rocks. These are (1) a mantle wedge with lead isotope composition similar to the Philippine Sea basalts, (2) subducted terrigenous sediments with an EM2-type isotope signature, and (3) a slabderived fluid component. As shown in plots of ${ }^{87} \mathrm{Sr} /{ }^{86} \mathrm{Sr}$ and ${ }^{14.3} \mathrm{Nd} /{ }^{144} \mathrm{Nd}$ vs. ${ }^{206} \mathrm{~Pb} /{ }^{204} \mathrm{~Pb}$ ratios (Fig. 5), the northern Luzon arc volcanics exhibit a unique vertical trend that can be interpreted by incorporation of the South China Sea sediments with EM2-type isotope compositions of ${ }^{87} \mathrm{Sr}{ }^{\beta 6} \mathrm{Sr} \approx 0.7130$, ${ }^{143} \mathrm{Nd} /{ }^{144} \mathrm{Nd} \approx 0.5122$, and ${ }^{206} \mathrm{~Pb} /{ }^{204} \mathrm{~Pb} \approx 18.5$ (McDermott et al., 1993). On the other hand, the Kuanhsi-Chutung basalts delineate a distinct array pointing toward the EM1 component defined on the basis of oceanic basalts (Zindler and Hart, 1986). These intraplate basalts from northwestern Taiwan are the first volcanic group showing an EM1-type isotope signature in South China and adjacent regions.

\section{Origin of the EM-Type Sources}

Considering the absence of mantle plumes and conte nporaneous subduction beneath the present-day South China con- 
Table 1. Chemical and isotopic composition of Miocene basalts, NW Taiwan

\begin{tabular}{|c|c|c|c|c|c|c|c|c|c|c|}
\hline Locality & Kungk & uan area & 23-20 Ma) & Kuanh & si-Chutun & g area $(13$ & 3-9 Ma) & & & \\
\hline Sample & $\mathrm{TN}-4$ & TB-07 & TB-11 & $L-302$ & $\mathbf{M}-30$ & N-209 & M-604 & $S-14$ & $5-03$ & W-39 \\
\hline Type* & $\overline{\mathrm{AB}}$ & $\overline{A B}$ & $\overline{\mathrm{AB}}$ & $\mathrm{BA}$ & $\mathrm{AB}$ & $\overline{\mathrm{AB}}$ & H-K & TB & $\mathrm{TH}$ & TH \\
\hline \multicolumn{11}{|c|}{ Major elements (wt.\%) } \\
\hline $\mathrm{SiO}_{2}$ & 44.60 & 46.97 & 47.01 & 42.26 & 45.06 & 46.46 & 46.75 & 47.08 & 52.00 & 53.81 \\
\hline $\mathrm{TiO}_{2}$ & 2.73 & 3.16 & 3.23 & 3.21 & 3.00 & 2.82 & 3.29 & 2.09 & 1.46 & 1.39 \\
\hline $\mathrm{Al}_{2} \mathrm{O}_{3}$ & 13.25 & 16.15 & 16.26 & 12.49 & 16.59 & 13.58 & 14.85 & 13.60 & 14.08 & 15.00 \\
\hline $\mathrm{Fe}_{2} \mathrm{O}_{3}$ & 12.04 & 12.21 & 12.27 & 12.56 & 11.92 & 10.77 & 11.07 & 10.75 & 9.79 & 9.35 \\
\hline Mno & 0.19 & 0.17 & 0.18 & 0.18 & 0.17 & 0.16 & 0.16 & 0.16 & 0.14 & 0.12 \\
\hline $\mathrm{MgO}$ & 9.65 & 4.88 & 4.67 & 11.40 & 9.15 & 9.19 & 4.47 & 8.97 & 6.87 & 6.00 \\
\hline $\mathrm{CaO}$ & 8.90 & 7.31 & 7.62 & 9.21 & 8.59 & 8.32 & 6.80 & 9.95 & 8.53 & 8.08 \\
\hline $\mathrm{Na}_{2} \mathrm{O}$ & 3.49 & 3.94 & 3.74 & 3.80 & 3.57 & 3.48 & 2.99 & 2.59 & 3.01 & 3.03 \\
\hline $\mathrm{K}_{2} \mathrm{O}$ & 1.10 & 2.16 & 2.22 & 0.49 & 2.05 & 2.13 & 4.55 & 1.50 & 0.54 & 0.72 \\
\hline $\mathrm{P}_{2} \mathrm{O}_{5}$ & 0.65 & 0.89 & 0.90 & 0.90 & 0.93 & 0.84 & 0.90 & 0.51 & 0.28 & 0.31 \\
\hline L.O.I. & 3.63 & 1.35 & 1.12 & 3.08 & 1.64 & 1.84 & 3.35 & 2.31 & 2.84 & 1.41 \\
\hline Total & 100.21 & 99.19 & 99.22 & 99.58 & 99.67 & 99.59 & 99.18 & 99.51 & 99.54 & 99.22 \\
\hline \multicolumn{11}{|c|}{ Trace elements (ppm) } \\
\hline $\mathrm{Rb}$ & 12 & 49 & 52 & 9 & 37 & 40 & 119 & 42 & 25 & 12 \\
\hline $\mathrm{Ba}$ & 883 & 639 & 669 & 852 & 859 & 971 & 715 & 582 & 245 & 235 \\
\hline Th & 6.0 & 4.8 & 4.8 & 7.0 & 10.0 & 9.6 & 7.9 & 5.2 & 2.7 & 3.1 \\
\hline $\mathrm{U}$ & 1.3 & 1.0 & 1.1 & 1.6 & 1.8 & 1.6 & 1.3 & 1.0 & 0.58 & \\
\hline $\mathrm{Nb}$ & 82 & 61 & 64 & 70 & 82 & 71 & 74 & 46 & 24 & 25 \\
\hline $\mathrm{Ta}$ & 4.8 & 4.0 & 3.8 & 4.3 & 5.1 & 4.5 & 5.0 & 2.6 & 1.2 & 1.3 \\
\hline $\mathrm{Sr}$ & 749 & 883 & 1010 & 795 & 967 & 897 & 1436 & 576 & 352 & 378 \\
\hline $\mathrm{Zr}$ & 299 & 286 & 301 & 277 & 350 & 312 & 316 & 187 & 130 & 139 \\
\hline Hf & 6.8 & 7.0 & 6.6 & 6.6 & 8.4 & 6.7 & 7.4 & 4.4 & 3.1 & 3.3 \\
\hline$Y$ & 25 & 35 & 37 & 32 & 34 & 31 & 43 & 27 & 17 & 14 \\
\hline V & 233 & 192 & 191 & 251 & 218 & 183 & 226 & 191 & 145 & 106 \\
\hline $\mathrm{Ga}$ & & 22 & 23 & 19 & 22 & 21 & 25 & 19 & 20 & 20 \\
\hline $\mathrm{Cu}$ & 43 & 41 & 40 & 69 & 40 & 49 & 78 & 55 & 37 & 40 \\
\hline $\mathrm{Zn}$ & 112 & 107 & 105 & 97 & 113 & 93 & 111 & 103 & 103 & 101 \\
\hline Sc & 21 & 15 & 15 & 23 & 21 & 21 & 17 & 23 & 16 & 15 \\
\hline Co & & 42 & 40 & 61 & 75 & 49 & 32 & 55 & 45 & 44 \\
\hline $\mathrm{Ni}$ & 225 & 39 & 32 & 327 & 213 & 204 & 43 & 190 & 154 & 163 \\
\hline $\mathrm{Cr}$ & 285 & 28 & 12 & 454 & 294 & 247 & 5 & 314 & 270 & 249 \\
\hline $\mathrm{La}$ & 52.8 & 52.8 & 45.2 & 61.9 & 66.2 & 62.8 & 54.7 & 34.7 & 17.0 & 19.8 \\
\hline $\mathrm{Ce}$ & 103 & 103 & 98.5 & 116 & 134 & 122 & 103 & 63.2 & 34.9 & 38.5 \\
\hline Nd & 51.8 & 53.0 & 52.0 & 54.9 & 61.0 & 55.1 & 51.6 & 32.2 & 17.7 & \\
\hline Sm & 9.0 & 10.2 & 10.2 & 10.2 & 11.3 & 10.0 & 10.5 & 6.5 & 4.4 & 4.4 \\
\hline Eu & 2.9 & 3.3 & 3.1 & 3.2 & 3.5 & 3.2 & 3.0 & 2.2 & 1.5 & 1.5 \\
\hline Tb & 1.2 & 1.2 & 1.1 & 1.3 & 1.4 & 1.4 & 1.3 & 0.96 & 0.60 & 0.72 \\
\hline $\mathrm{Yb}$ & 2.1 & 2.3 & 2.2 & 2.1 & 2.1 & 2.1 & 2.4 & 2.0 & 1.3 & 1.3 \\
\hline Lu & 0.29 & 0.35 & 0.33 & 0.31 & 0.29 & 0.31 & 0.34 & 0.28 & 0.21 & 0.19 \\
\hline \multicolumn{11}{|l|}{ Isotope ratios } \\
\hline${ }^{87} \mathrm{Sr} / 86 \mathrm{Sr}$ & 0.70359 & 0.70358 & 0.70362 & 0.70403 & 0.70485 & 0.70504 & 0.70559 & 0.70463 & 0.70497 & 0.70555 \\
\hline${ }^{87} \mathrm{Sr}^{86} \mathrm{Sr}^{\dagger}$ & & & & & & 0.70496 & 0.70550 & 0.70424 & & 0.70543 \\
\hline${ }^{143} \mathrm{Nd} / 144 \mathrm{Nd}$ & 0.51292 & 0.51294 & 0.51289 & 0.51282 & 0.51270 & 0.51265 & 0.51268 & 0.51280 & 0.51263 & 0.51257 \\
\hline${ }^{206} \mathrm{~Pb} / 204 \mathrm{~Pb}$ & 18.647 & 18.802 & 18.790 & 18.342 & 18.047 & 17.985 & 17.972 & 18.223 & 17.958 & 17.654 \\
\hline${ }^{207} \mathrm{~Pb} / 204 \mathrm{~Pb}$ & 15.567 & 15.572 & 15.566 & 15.571 & 15.629 & 15.629 & 15.557 & 15.574 & 15.566 & 15.569 \\
\hline $208 \mathrm{~Pb} / 204 \mathrm{pb}$ & 38.769 & 38.920 & 38.889 & 38.555 & 38.703 & 38.547 & 38.403 & 38.561 & 38.255 & 38.074 \\
\hline \multicolumn{11}{|c|}{$\begin{array}{l}\text { * Rock types: } \mathrm{BA}=\text { basanite; } \mathrm{AB}=\text { alkali basalt; } \mathrm{TB}=\text { transitional basalt; } \mathrm{TH}=\text { tholeiite; } \mathrm{H}-\mathrm{K}=\text { highly potassic basalt. } \\
\text { Isotope determinations made by VG354 at Academia Sinica, Taipei and Finnigan MAT262 at the Universite de Rennes. }\end{array}$} \\
\hline \multicolumn{11}{|c|}{$\begin{array}{l}2 \text { standard errors are as follows: } 0.00004 \text { (Taipei) and } 0.00001 \text { (Rennes) for }{ }^{87} \mathrm{Sr} / 86 \mathrm{Sr} ; 0.00002 \text { (T aipei) and } \\
0.00001 \text { (Rennes) for }{ }^{143} \mathrm{Nd} / 144_{\mathrm{Nd}} \text {; and less than } 0.1 \% \text { for all } \mathrm{Pb} \text { isotope ratios. }\end{array}$} \\
\hline \multicolumn{11}{|c|}{$\begin{array}{l}\text { Sr and Nd isotopes reported relative to }{ }^{87} \mathrm{Sr} /{ }^{86} \mathrm{Sr}=0.71020 \text { for the NBS } 987 \text { and }{ }^{143} \mathrm{Nd} / 144 \mathrm{Nd}=0.511860 \\
\text { for the La Jolla, respectively. Pb isotope ratios corrected by } 0.1 \% \text { per unit mass against the NBS } 981 \text {. } \\
\text { i Sr isotope ratios determined after acid leaching }\end{array}$} \\
\hline
\end{tabular}

tinent, geochemical arguments (Tu et al., 1991, 1992; Chung et al., 1994) favor that the EM2-type isotope signature shared by late Cenozoic basalts in this region was derived from the continental lithospheric mantle. Such a continental mantle source may have been thermomechanically eroded and mixed into the convecting asthenosphere during extension of the South China continental margin in the late Cretaceous (Taylor and Hayes, 1983). To explain the spatial chemical and isotopic variation observed in the Fujian-Taiwan basalts, Chung et al. (1994) proposed a "plum-pudding"' type convecting mantle model, in which the "plums," with EM2-type isotope character, were added from the lower part of the lithospheric mantle.

In Fig. 5, the correlation between different radiogeneic isotope ratios suggests that the Kuanhsi-Chutung basalts resulted from a binary mixing process, requiring additional involvement of an EM1-type component. The mixing must have taken place rather recently, otherwise these linear arrays would have been destroyed or severely degraded by radiogenic isotope growth. Relatively low ${ }^{206} \mathrm{~Pb} /{ }^{04} \mathrm{~Pb}$ and 


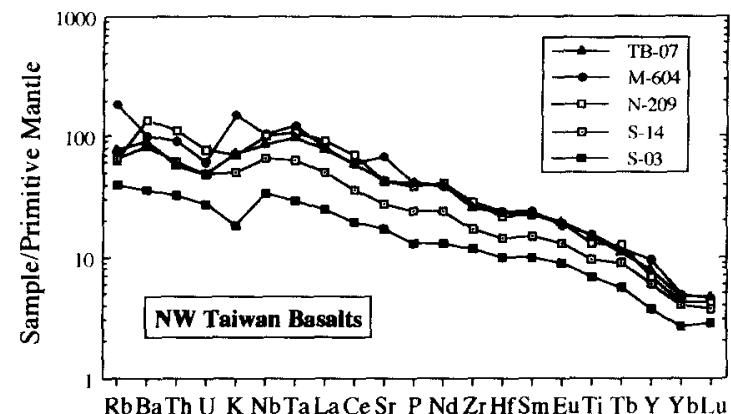

FlG. 2. Spidergrams for the Miocene basalts in northwestern Taiwan. Sample TB-7 is representative of the Kungkuan basalts, whereas the others show different basalt types from the Kuanhsi-Chutung area. The normalizing values for Primitive Mantle are from Sun and McDonough (1989).

${ }^{143} \mathrm{Nd} /{ }^{144} \mathrm{Nd}$ ratios in these basalts indicate time-integrated low $\mathrm{U} / \mathrm{Pb}$ and $\mathrm{Sm} / \mathrm{Nd}$ ratios in the EM1-type source, which may represent either an ancient metasomatized lithospheric mantle (Menzies et al., 1987) or a lower crustal granulite assemblage (Ben Othman et al., 1984). Existence of ancient continental lithosphere beneath South China, since at least the mid-Proterozoic, is consistent with the Sm-Nd isotope data for granitoids and metasediments (Lan, 1989; Chen Chen-Hong et al., 1990; Jahn et al., 1990). However, the granulite contribution seems unlikely because the Kuanhsi-Chutung basalts have coherent elemental ratios similar to the other Fujian-Taiwan basalts (Table 1; Chung et al., 1994, and unpubl. data). They do not show Nb-Ta depletions (Fig. 2), that are commonly observed in lower crustal lithologies (Jahn, 1990; Rudnick and Presper, 1990). Moreover, in the Kuanhsi-Chutung area basanites and alkali basalts occasionally contain ultramafic xenoliths from the uppermost lithospheric mantle (ca. $30 \mathrm{~km}$ depth; Chung, 1990). This reflects rapid magma ascent to crustal levels, thus implying little residence time to interact with the lower continental crust. We therefore suggest that the EM1-type isotope signature may have been derived from the continental lithospheric mantle.

Prior to the Cenozoic continental rifting in South China, it is generally believed that subduction of the paleo-Pacific plate underneath Eurasia may have been a major tectonic process over a long time period in this region. The EM2-type isotope signature in the continental lithospheric mantle has been considered to be related to supra-subduction processes in the Mesozoic (Tu et al., 1991, 1992; Flower et al., 1992). Since South China was a fragment rifted from Gondwanaland (Lin et al., 1985), the EM-type components (both EM1 and EM2) may have been inherited from this supercontinent. Processes of ancient subduction or plume-related intraplate magmatism may have imparted EM-type signatures into the Gondwana lithosphere in the southern hemisphere (Chung et al., 1994). Information provided by mantle xenoliths in the late Cenozoic basalts can help better constrain the mechanism(s) that metasomatized the continental lithospheric mantle beneath South China. Zhang et al. (1995) advocated subduction-induced modification processes, in accordance with their argument based on the basalt chemistry (Flower et al., 1992; Tu et al., 1992), to reconcile ion microprobe data for clinopyroxenes in mantle xenoliths from Hainan Island. In addition, Menzies et

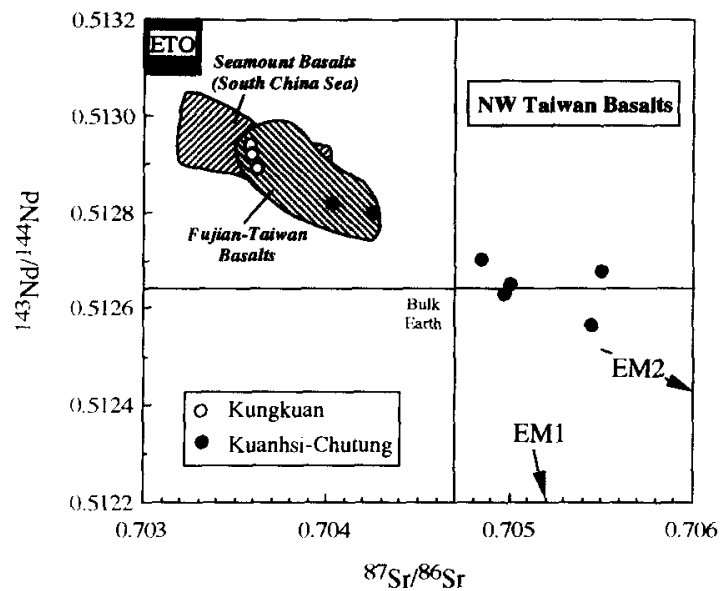

Fig. 3. Plots of ${ }^{87} \mathrm{Sr} /{ }^{86} \mathrm{Sr}$ vs. ${ }^{14.3} \mathrm{Nd} /{ }^{144} \mathrm{Nd}$ for Miocene basalts in northwestern Taiwan. Fields for the East Taiwan Ophiolite (ETO), seamount basalts from the South China Sea and the Fujian-Taiwan basalts are after Tu et al. (1992), Chung and Sun (1992), and Chung et al. (1994; and unpubl. data).

al. (1993) noted that mantle xenoliths from the same area have elevated thorium and lead abundances, thus supporting enrichment related to sediment subduction. However, the subduction-related metasomatism model appears to be in contradiction with the elemental characteristics of late Cenozoic basalts in South China because all these recent basalts lack arc-like geochemical features such as $\mathrm{Nb}$-Ta depletions.

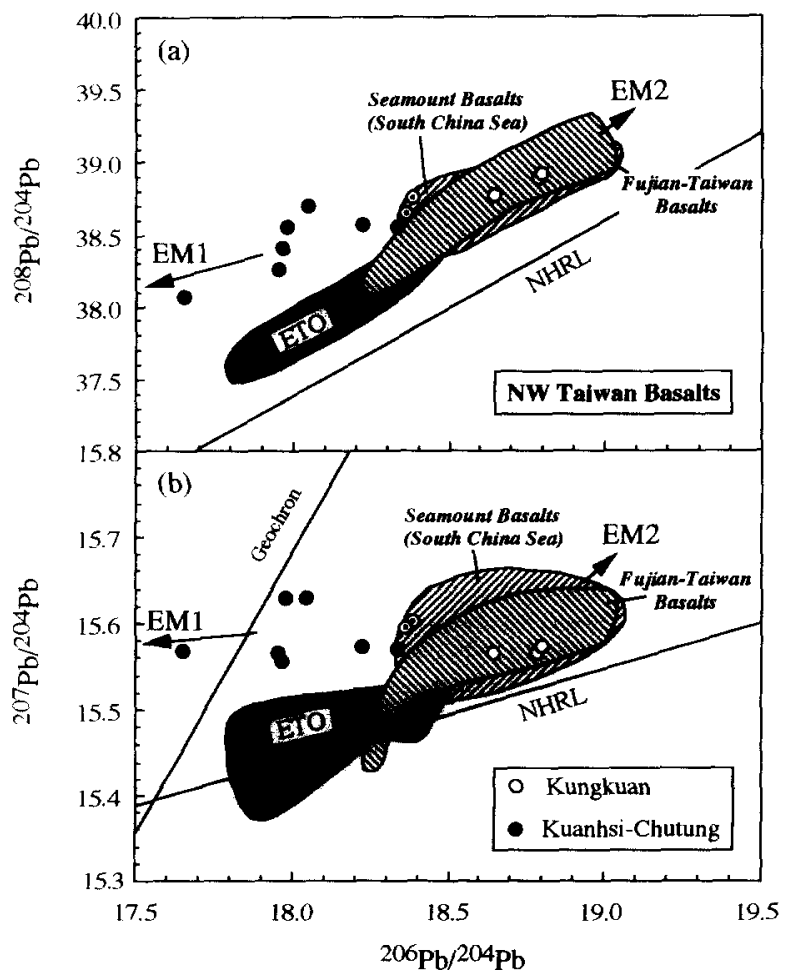

FIG. 4. (a) ${ }^{208} \mathrm{~Pb} /{ }^{204} \mathrm{~Pb}$ and (b) ${ }^{207} \mathrm{~Pb} /{ }^{204} \mathrm{~Pb}$ vs. ${ }^{216} \mathrm{~Pb} /{ }^{04} \mathrm{~Pb}$ diagrams. Data sources are the same as Fig. 3. Two late Miocene basalts (dotted circle) from the Chiaopanshan area (Sun, 1980) show consistent lead isotope ratios plotting on the trend defined by the Kuanhsi-Chutung basalts. NHRL = northern hemisphere reference line (Hart, 1984). 


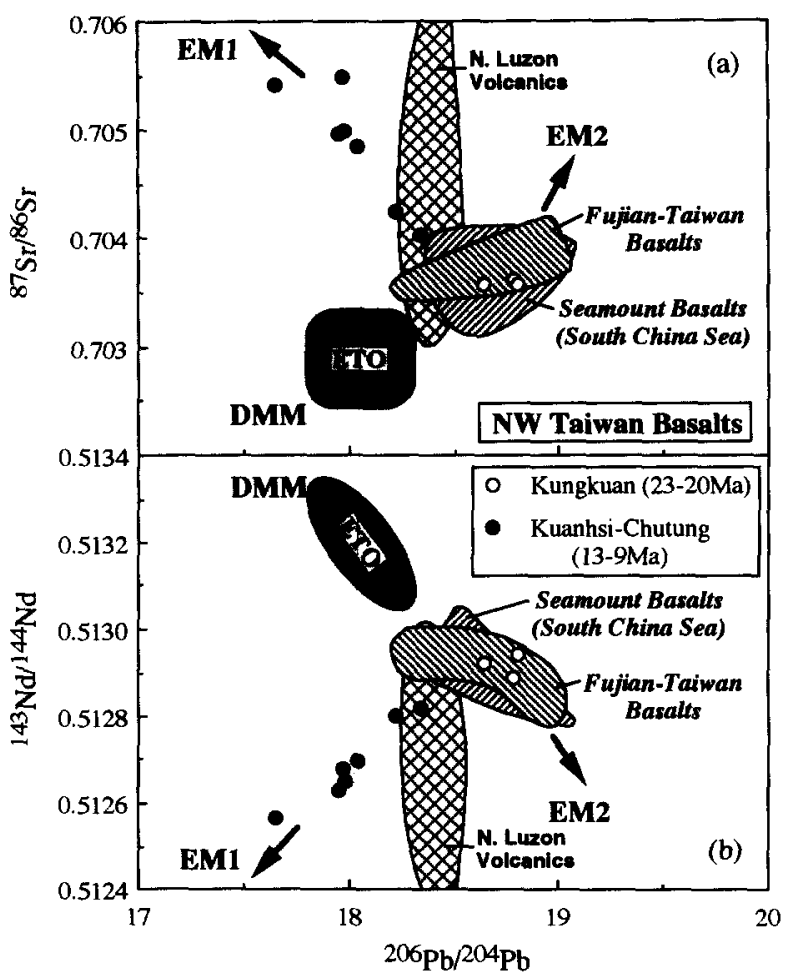

FIG. 5. Plots of (a) ${ }^{87} \mathrm{Sr} /{ }^{86} \mathrm{Sr}$ and (b) ${ }^{143} \mathrm{Nd} /{ }^{144} \mathrm{Nd}$ vs. ${ }^{206} \mathrm{~Pb} /{ }^{204} \mathrm{~Pb}$ showing incorporation of two types of enriched mantle reservoirs in the generation of northwestern Taiwan basalts. The vertical isotope field of the northern Luzon are volcanics (after McDermott et al., 1993) is also illustrated. The depleted mantle (DMM) and enriched mantle (EM1 and EM2) components are taken from Zindler and Hart (1986).

Although the subduction-related origin seems unfavored, late Cretaceous and early Tertiary intraplate basaltic rocks emplaced in the Fujian-Taiwan region do show Nb-Ta negative anomalies in mantle normalized diagrams (Lapierre et al., 1995; Lee, 1994). Relevant chemical and isotopic evidence indicates that such a distinct feature may have been derived from the continental lithospheric mantle rather than crustal contamination (Lee, 1994). It has been suggested that if the continental lithospheric mantle has been previously affected by subduction-related processes, recurrent upward migration of intraplate melts may overprint, or even erase, the subduction-related enrichment (Sun et al., 1989). We apply this scenario to the South China continental margin and propose that both types of enriched components (i.e., EM1 and EM2) in the lithospheric mantle could have been produced by subduction zone processes (of the Gondwana and Mesozoic age). Likewise, some other mechanisms such as intraplate magmatism may have modified certain geochemical features formed by earlier subduction processes.

\section{Involvement of EM-Type Reservoirs in the Magma Genesis}

Compared with the prevailing EM2-type isotope character in South China (Tu et al., 1992; Chung et al., 1994), the paucity of EM1-type signature in this region implies the existence of a restricted reservoir in the continental lithospheric mantle.
Involvement of such a continental reservoir in magma generation has resulted in a striking change to the isotope composition of Miocene basalts in northwestern Taiwan. This change may be attributed to the switch in tectonic environment from extensional to arc-continent collisional regime in the Fujian-Taiwan region. The collision resulted in a westward cessation of intraplate volcanism around the Taiwan Strait (Chung et al., 1994).

We propose that, as for the other Fujian-Taiwan basalts (Chung et al., 1994), decompression melting of the convecting mantle intermingling with EM2-type "plums" produced the early Miocene alkali basalts in the Kungkuan area. In this model, the plum component is suggested to have originated from the basal lithospheric mantle through thermomechanical erosion processes caused by upwelling of the convecting mantle. Since the late Miocene, collision-induced compression may have stagnated magma ascent which then heated up and triggered melting of the EM1-type reservoir located in the lithospheric mantle. Consequently, volcanics occurring in the Kuanhsi-Chutung area became chemically and isotopically heterogeneous due to various degrees of incorporation of melts generated at shallower levels with EM1-type isotope character

\section{Broader Implication for Mantle Processes in Eastern China}

Similar dynamic processes for magma generation and lithospheric mantle evolution may have taken place in other $\mathrm{Ce}$ nozoic extension provinces in eastern China. Specifically, Song et al. (1990) conducted a detailed $\mathrm{Sr}-\mathrm{Nd}-\mathrm{Pb}$ isotope study on the Miocene basalts from the Hannuoba area in northern China which are marked by striking chemical and isotopic variations. These authors proposed that decompression melting of the upwelling asthenosphere resulted in the Hannuoba alkali basalts, whilst the associated tholeiites resulted from additional melting of an EM1-type reservoir in the reactivated lithospheric mantle. Such an enriched mantle source is best documented by the Quaternary ultrapotassic rocks from the Wudalianchi area, northeastern China (Basu et al., 1991; Zhang et al., 1991). These volcanics have the lowest lead $\left({ }^{206} \mathrm{~Pb} /{ }^{204} \mathrm{~Pb} \approx 16.5\right.$ ) and neodymium ( $\epsilon \mathrm{Nd}$ $\approx-12$ ) isotope ratios among the Cenozoic intraplate basalts in eastern China (Zhang, 1992), suggesting a significant contribution from an ancient metasomatized lithospheric mantle source.

Isotopic and elemental data for the basalt-borne mantle xenoliths support the idea of presence of EM-type reservoirs in the continental lithospheric mantle beneath several extensional regions in eastern China (Tatsumoto et al., 1992; Menzies et al., 1993). Regarding eastern China as a diverse continental assemblage of stable cratons and younger folded terranes which amalgamated and then underwent a complex tectonic history, Menzies et al. (1993) postulated that the lithospheric mantle is a hybrid comprising old cratonic nuclei and more recently accreted peridotites with lateral and vertical geochemical variations reflective of modifications by different processes.

Tu et al. (1989) and Zartman et al. (1991) suggested that the Dupal-like lead isotope feature, observed in Cenozoic in- 
traplate basalts in eastern China, is accompanied by a general southward increase in ${ }^{206} \mathrm{~Pb} /{ }^{204} \mathrm{~Pb}$ ratio from an $\mathrm{EM} 1$-type to an EM2-type composition, which they explained as reflecting a change of the geotectonic settings across cratonic, circumcratonic, and oceanic domains. However, this scenario of spatial lead isotope variation is probably false because the EM1type isotope signature prevalent in the north is also recorded by basalts from central China (Peng et al., 1986) and northwestern Taiwan. Since most Cenozoic basalts in eastern China show chemical and isotopic characteristics similar to those of oceanic island basalts, crustal contamination is generally believed to have played an insignificant role in magma generation. The geochemical similarity and heterogeneity of these intraplate basalts should link genetically with involvement of the continental lithospheric mantle reservoirs which may have diverse origins and distinct compositions resulting from complex geotectonic histories for the extensional provincecs in eastern China.

Acknowledgments - We thank M. LeCoz-Bouhnik, O. Henin, J Macé, N. Morin (Rennes), and Jason J. S. Shen (Taipei) for assistance in chemical and isotopic analyses. Constructive reviews provided by M. A. Menzies, F. A. Frey, S.-s. Sun, and Y. Tatsumi were of great help in clarifying many aspects of this paper. S. L. Chung has benefited from a postdoctoral grant financed by C.N.R.S. (France) and N.S.C. (ROC-Taiwan). This study was completed through a research grant (NSC83-0202-M002-006) sponsored by the National Science Council (ROC-Taiwan).

\section{Editorial handling: M. Menzies}

\section{REFERENCES}

Basu A. R., Wang J. W., Huang W. K., Xie G. H., and Tatsumoto M. (1991) Major element, REE, and Pb, Nd, and Sr isotopic geochemistry of Cenozoic volcanic rocks of eastern China: implications for their origin from sub-oceanic type mantle reservoirs. Earth. Planet. Sci. Lett. 105, 149-169.

Ben Othman D., Polvé M., and Allègre C. J. (1984) Nd-Sr isotopic composition of granulites and constraints on the evolution of the lower continental crust. Nature 307, 510-515.

Chen Chang-Hwa, Shieh Y. N., Lee T., Chen C-H., and Mertzman S. A. (1990) Nd-Sr-O isotopic evidence for source contamination and an unusual mantle component under Luzon Arc. Geochim. Cosmochim. Acta 54, 2473-2483.

Chen Cheng-Hong (1990) The Igneous Rocks in Taiwan. Centrat Geological Survey (Taiwan), Publ. I (in Chinese).

Chen Chen-Hong, Jahn B. M., Lee T., Chen C. H., and Cornichet J. (1990) Sm-Nd isotopic geochemistry of sediments from Taiwan and implications for the tectonic evolution of southeast China. Chem. Geol. 88, 317-332.

Chung S. L. (1990) Geochemistry of megacrysts and xenoliths in alkali basalts from western Taiwan. Ph.D. dissertation, National Taiwan University (in Chinese).

Chung S. L. and Sun S.-s. (1992) A new genetic model for the East Taiwan Ophiolite and its implications for Dupal domains in the Northern Hemisphere. Earth Planet. Sci. Lett. 109, 133-145.

Chung S. L., Sun S.-s., Tu K., Chen C-H., and Lee C. Y. (1994) Late Cenozoic basaltic volcanism around the Taiwan Strait, SE China: product of lithosphere-asthenosphere interaction during continental extension. Chem. Geol. 112, 1-20.

Flower M. F. J., Zhang M., Chen C. Y., Tu K., and Xie G. H. (1992) Magmatism in the South China Basin, 2. Post-spreading Quaternary basalts from Hainan Island, south China. Chem. Geol. 97, 6587.

Hart S. R. (1984) A large isotope anomaly in the Southern Hemisphere mantle. Nature 309, 753-757.
Ho C. S. (1986) A synthesis of the geological evolution of Taiwan. Tectonophysics 125, 1-16.

Jahn B. M. (1990) Origin of granulites: geochemical constraints from Archean granulite facies rocks of the Sino-Korean craton, China. In Granulites and Crustal Evolution (ed. D. Vielzeuf and $\mathrm{Ph}$. Vidal), pp. 471-492. Kluwer.

Jahn B. M., Zhou X. H., and Li J. L. (1990) Formation and tectonic evolution of southeastern China and Taiwan: isotopic and geochemical constraints. Tectonophysics 183, 145-160.

Lan C. Y. (1989) Geochronology and rock chemistry of Taiwan gneisses. Ph.D. dissertation, National Taiwan University (in Chinese).

Lapierre H., Jahn B. M., Charvet J., and Yu Y. W. (1995) Mesozoic magmatism in Zhejiang Province and its relation with the tectonic activities in SE China. Earth Planet. Sci. Lett. (submitted).

Lee C. Y. (1994) Chronology and geochemistry of basaltic rocks from Penghu Islands and mafic dykes from eastern Fujian. Ph.D. dissertation, National Taiwan University (in Chinese).

Lin J., Fuller M., and Zhang W. (1985) Preliminary Phanerozoic polar wander paths for the North and South China blocks. Nature 313, 444-449.

McDermott F., Defant M. J., Hawkesworth C. J., Maury R. C., and Joron J. L. (1993) Isotope and trace element evidence for three component mixing in the genesis of North Luzon arc lavas (Philippines). Contrib. Mineral. Petrol. 113, 9-23.

Menzies M. A., Rogers N., Tindle A., and Hawkesworth C. J. (1987) Metasomatic and enrichment processes in lithospheric peridototes: an effect of asthenosphere-lithosphere interaction. In Mantle Metasomatism (ed. M. A. Menzies and C. J. Hawkesworth), pp. 313361. Academic Press

Menzies M. A., Fan W. M., and Zhang M. (1993) Paleozoic and Cenozoic lithoprobes and the loss of $>120 \mathrm{~km}$ of Archean lithosphere, Sino-Korean Craton, China. In Magmatic Processes and Plate Tectonics (ed. H. M. Prichard et al.); Geol. Soc. Spec. Publ. 76, $71-81$.

Peng Z. C., Zartman R. E., Futa K., and Chen D. G. (1986) Pb-, Srand $\mathrm{Nd}$-isotopic systematics and chemical characteristics of $\mathrm{Ce}$ nozoic basalts, eastern China. Chem. Geol. 59, 3-33.

Rudnick R. L. and Presper T. (1990) Geochemistry of intermediateto high-pressure granulites. In Granulites and Crustal Evolution (ed. D. Vielzeuf and P. Vidal), pp. 523-550. Kluwer.

Song Y., Frey F. A., and Zhi X. C. (1990) Isotopic characteristics of Hannuoba basalts, eastern China: implications for their petrogenesis and the composition of subcontinental mantle. Chem. Geol. $85,35-52$.

Sun S.-s. (1980) Lead isotopic study of young volvanic rocks from mid-ocean ridges, ovean islands and island arcs. Philos. Trans. Roy Soc. London, A 297, 409-455.

Sun S.-s. and McDonough W. F. (1989) Chemical and isotopic systematics of oceanic basalts: implications for mantle composition and processes. In Magmatism in the Ocean Basins (ed. A. D. Sanders and M. J. Norry); Geol. Soc. Spec. Publ. 42, 313-345.

Sun S.-S., McDonough W. F., and Ewart A. (1989) Four component dynamic model for East Australian basalts. In Intraplate Volcanism in Eastern Australia and New Zealand (ed. R. W. Johnson), pp. 333-347. Cambridge Univ. Press.

Suppe J. (1981) Mechanics of mountain-building and metamorphism in Taiwan. Mem. Geol. Soc. China 4, 67-90.

Tapponnier P., Peltzer G., and Armiro R. (1986) On the mechanics of the collision between India and Asia. In Collision Tectonics (ed. M. P. Coward and A. C. Ries); Geol. Soc. Spec. Publ. 19, 115-157.

Tatsumi Y., Otofuji Y., Matsuda T., and Nohda S. (1989) Opening of the Sea of Japan back-arc basin as asthenospheric injection. Tectonophysics 166, 317-329.

Tatsumoto M., Basu A. R., Huang W. K., Wang J. W., and Xie G. H. (1992) $\mathrm{Sr}$, $\mathrm{Nd}$ and $\mathrm{Pb}$ isotopes of ultramafic xenoliths in volcanic rocks of eastern China: enriched components EM1 and EM2 in subcontinental lithosphere. Earth Planet. Sci. Lett. 113, $107-128$.

Taylor B. and Hayes D. E. (1983) Origin and history of the South China Basin. In The Tectonic and Geological Evolution of Southeast Asian Seas and Islands (ed. D. E. Hayes); Geophys. Monogr. 27, 25-56. Amer. Geophys. Union. 
Teng L. S. (1990) Geotectonic evolution of late Cenozoic arc-continent collision in Taiwan. Tectonophysics 183, 57-76.

Tu K., Flower M. F. J., Xie G. H., Carlson R. W., Wang Q., and Zhang M. (1989) Lead isotopic data for Cenozoic basalts from eastern China: evidence for cratonic and circum-cratonic mantle domains. Abst. 28th I.G.C. 3, 260-261.

Tu K., Flower M. F. J., Carlson R. W., Zhang M., and Xie G. H. (1991) $\mathrm{Sr}, \mathrm{Nd}$, and $\mathrm{Pb}$ isotopic compositions of Hainan basalts (south China): implications for a subcontinental lithosphere Dupal source. Geology 19, 567-569.

Tu K., Flower M. F. J., Carlson R. W., Zhang M., and Xie G. H. (1992) Magmatism in the South China Basin, 1. Isotopic and trace element evidence for an endogenous Dupal mantle component. Chem. Geol. 97, 47-63.

Yen T. P. (1958) Cenozoic volcanic activity in Taiwan. Taiwan Min. Ind. 10, 1-39.
Zartman R. E., Futa K., and Peng Z. C. (1991) A comparison of Sr$\mathrm{Nd}-\mathrm{Pb}$ isotopes in young and old continental lithospheric mantle: Patagonia and eastern China. Australian J. Earth Sci. 38, 545557.

Zhang J. B. (1992) Characteristics of the ultrapotassic rocks in NE China and implications for regional mantle geochemistry. Ph.D. dissertation, Inst. Geol., Acad. Sinica, Beijing (in Chinese).

Zhang M., Menzies M. A., Suddaby P., and Thirlwall M. F. (1991) EM1 signature from within the post-Archean subcontinental lithospheric mantle: Isotopic evidence from the potassic volcanic rocks in NE China. Geochem. J. 25, 387-398.

Zhang M., Flower M. F. J., and Shimizu N. (1995) Diversification of continental lithospheric mantle: a study of mantle xenoliths and clinopyroxenes. Chem. Geol. (submitted).

Zindler A. and Hart S. R. (1986) Chemical geodynamics. Annu. Rev. Earth Planet. Sci. 14, 493-571. 